\title{
Characterization of a Listeria monocytogenes meningitis mouse model
}

\author{
Merel M. Koopmans, JooYeon Engelen-Lee, Matthijs C. Brouwer, Valery Jaspers, Wing Kit Man, \\ Mercedes Vall Seron and Diederik van de Beek
}

\begin{abstract}
Background: Listeria monocytogenes is a common cause of bacterial meningitis. We developed an animal model of listerial meningitis.

Methods: In survival studies, C57BL/6 mice received intracisternal injections with different L. monocytogenes sequence type 1 (ST1) colony forming units per milliliter (CFU; $n=48,10^{5}, 10^{6}, 10^{7}, 10^{8}$, and $10^{9} \mathrm{CFU} / \mathrm{ml}$ ). Second, mice were inoculated with $10^{8} \mathrm{CFU} / \mathrm{ml} \mathrm{ST1}$ and sacrificed at $6 \mathrm{~h}$ and $24 \mathrm{~h}$ ( $n=12 /$ group). Outcome parameters were clinical score, CFUs, cyto- and chemokine levels, and brain histopathology. Third, 84 mice were inoculated $\left(10^{9} \mathrm{CFU} / \mathrm{ml}\right.$ ST1) to determine optimal antibiotic treatment with different doses of amoxicillin and gentamicin. Fourth, mice were inoculated with $10^{9} \mathrm{CFU} / \mathrm{ml} \mathrm{ST1}$, treated with amoxicillin, and sacrificed at $16 \mathrm{~h}$ and $24 \mathrm{~h}$ ( $\mathrm{n}=12 / \mathrm{group}$ ) for outcome assessment. Finally, time point experiments were repeated with ST6 ( $n=24 /$ group).

Results: Median survival time for inoculation with $10^{8}$ and $10^{9} \mathrm{CFU} / \mathrm{ml} \mathrm{ST1}$ was $46 \mathrm{~h}$ and $40 \mathrm{~h}$; lower doses of bacteria led to minimal clinical signs of disease. Brain levels of IL-6, IL-17A, and IFN- $\gamma$ were elevated at $24 \mathrm{~h}$, and IL-1 $\beta, I L-6, I L-10, I F N-\gamma$, and TNF-a were elevated in blood at $6 \mathrm{~h}$ and $24 \mathrm{~h}$. Histopathology showed increased meningeal infiltration, vascular inflammation of meningeal vessels, hemorrhages, and ventriculitis. In the treatment model, brain levels of IL-6 and IL-17A and blood levels of IL-6 and IFN- $\gamma$ were elevated. Compared to ST6, infection with ST1 led initially to higher levels of IL-1 $\beta$ and TNF- $\alpha$ in blood and more profound neuropathological damage. At $16 \mathrm{~h}$ post inoculation, IL-1 $\beta$, IL-10, and TNF-a in blood and IL-6, IL17A, TNF- $a$, and IFN- $\gamma$ levels in brain were higher in ST1 compared to ST6 without differences in CFUs between STs. At 24 h, neuropathology score was higher in ST1 compared to ST6 $(p=0.002)$ infected mice.
\end{abstract}

Conclusions: We developed and validated a murine model of listerial meningitis. ST1-infected mice had a more severe inflammatory response and brain damage as compared to ST6-infected mice.

Keywords: Listeria monocytogenes, Mouse model, Sequence type, Histopathology, Cytokines

\section{Background}

Bacterial meningitis is a life-threatening infectious disease of the central nervous system, which is most commonly caused by Streptococcus pneumoniae and Neisseria meningitidis [1, 2]. Listeria monocytogenes is the third most common pathogen causing bacterial meningitis in adults, and is found in $5-10 \%$ of cases [2-4]. Listeria distributes easily in the environment and can be found in soil, ground water, and feces of animals $[5,6]$. Main source for human

\footnotetext{
* Correspondence: d.vandebeek@amc.uva.nl

From the Amsterdam UMC, Department of Neurology, University of

Amsterdam, Amsterdam Neuroscience, Meibergdreef 9, 1105 AZ Amsterdam, The Netherlands
}

(c) The Author(s). 2018 Open Access This article is distributed under the terms of the Creative Commons Attribution 4.0 International License (http://creativecommons.org/licenses/by/4.0/), which permits unrestricted use, distribution, and reproduction in any medium, provided you give appropriate credit to the original author(s) and the source, provide a link to the Creative Commons license, and indicate if changes were made. The Creative Commons Public Domain Dedication waiver (http://creativecommons.org/publicdomain/zero/1.0/) applies to the data made available in this article, unless otherwise stated.

infection is food, and it primarily affects elderly and immunocompromised persons, [7] in whom it can cause up to $40 \%$ of community-acquired bacterial meningitis cases $[8,9]$. A nation-wide prospective cohort study on $L$. monocytogenes meningitis described an increasing mortality rate over time, from 17 to $36 \%$ over the past decade [10]. This trend was also reported by a French cohort study including 252 patients with listerial meningitis [7].

In the immune response neutrophils, monocytes and macrophages are activated by pro-inflammatory cytokines such as IL- $1 \alpha$, IL-1, IL-6, IL-12, TNF- $\alpha$, and IFN- $\gamma$ [11-14]. Anti-inflammatory cytokine IL-10 plays an important role in limiting immune-mediated damage and 
at the same time antagonizes IFN- $\gamma$ activity which makes the host more vulnerable for an invasive listerial infection [14]. Several mouse and rat listeria models have been developed to study invasive $L$. monocytogenes diseases including cerebral and meningeal infection, using oral [15-17], intravenous [18], intracerebral [19-23], or intracisternal inoculation methods [24-26]. Problems with reproducibility, limited disease progression, or iatrogenic structural damage, combined with a need for a single model in which most pathological features seen in human listerial meningitis can be measured, have created the need for development of a new animal model. We developed a listerial meningitis mouse model to counter these problems and compared infection with listerial ST1 with ST6.

\section{Methods}

Bacterial strain L. monocytogenes sequence type 1 (ST1) was used for the experiments, time point studies were repeated with a ST6 strain. Both strains were obtained from human positive cerebrospinal fluid (CSF) isolates stored at the Netherlands Reference Laboratory for Bacterial Meningitis (NRLBM). The isolates were grown to mid-log phase in $1-1.5 \mathrm{~h}$ at $37{ }^{\circ} \mathrm{C}$ in $\mathrm{BHI}$ to an optical density (OD600) of $0.45-0.55$, then, centrifuged at $2000 \mathrm{rpm}$ for $20 \mathrm{~min}$ at $4{ }^{\circ} \mathrm{C}$. Supernatant was removed, and sterile $0.9 \% \mathrm{NaCl}$ was added to yield the needed concentration. Before and after inoculation, the dose was determined by serial dilution method and plated on blood agar plates overnight at $37^{\circ} \mathrm{C}$.

Experiments were performed with eight- to ten-week-old C57BL/6 mice (Charles River Laboratories, Germany). In the non-treatment survival experiments, both sexes were used; in the non-treatment time point experiments and all treatment experiments, male C57BL/6 mice were used. The mice were kept to a controlled 12-h light/dark cycle, and food and water were provided ad libitum. All experiments were approved by the Institutional Animal Care and Use Committee of the Academic Medical Center, Amsterdam and performed according to the institution and Animal Research: Reporting of In Vivo Experiments (ARRIVE) guidelines [27].

\section{Mouse model of listerial meningitis: non-treatment}

Survival experiments were performed to determine clinical course of disease with the aim to achieve a median lethal dose for $50 \%$ of mice (LD50) after 36-48 h. Mice were inoculated with $1 \mu \mathrm{l}$ bacterial suspension L. monocytogenes ST1 into the cisterna magna using a 32-gauge needle and syringe to dispense $1-10 \mu \mathrm{l}$. During inoculation, mice received short-term anesthesia using $2 \%$ isoflurane (Baxter). Five inoculum sizes were tested between $10^{5}$ and $10^{9} \mathrm{CFU} / \mathrm{ml}\left(n=6\right.$ in $10^{5}$ and $10^{6} \mathrm{CFU} / \mathrm{ml}, n=12$ in $10^{7}$ and $10^{9} \mathrm{CFU} / \mathrm{ml}$ groups). After inoculation, mice were checked according to a clinical scoring list for direct neurological deficits which could indicate puncture failure (such as occipital bleeding). If direct neurological deficits were found, mice were euthanized and excluded from the experiment. Mice were monitored every 4-6 h (starting from $12 \mathrm{~h}$ after inoculation), and the clinical score (Table 1) and the portion of surviving mice in each group was determined up to $90 \%$ mortality [28]. Mice were sacrificed by intraperitoneal injection (i.p.) with dexmedetomidine $(0.3 \mathrm{mg} / \mathrm{kg})$ in combination with ketamine (190 $\mathrm{mg} / \mathrm{kg}$ ) when a clinical score of $\geq 15$ was reached. Subsequently, time point experiments were performed ( $n=12$ per time point) with $10^{8} \mathrm{CFU} / \mathrm{ml}$ L. monocytogenes ST1 or ST6 which were compared to a control group $(n=6)$ receiving $1 \mu \mathrm{l} 0.9 \% \mathrm{NaCl}$ intracisternally. At 6 and $24 \mathrm{~h}$ post-inoculation, mice were sacrificed, and blood, CSF, and organs were collected, processed, and stored [28, 29].

\section{Mouse model of listerial meningitis: treatment}

Three survival experiments with 84 male mice $(12$ mice per subgroup) were performed to test dosage and frequency of intraperitoneal amoxicillin treatment, and the potentially beneficial effect of adding intraperitoneal gentamicin, as is the preferred antibiotic treatment used in human listerial meningitis [30]. After each experiment, brains of one or two surviving mice per subgroup were harvested to measure bacterial outgrowth. In the first experiment, mice were inoculated with $10^{9} \mathrm{CFU} / \mathrm{ml}$ L. monocytogenes ST1 and treated $16 \mathrm{~h}$ post-inoculation with 50 or $100 \mathrm{mg} / \mathrm{kg}$ amoxicillin every $24 \mathrm{~h}$. In the second experiment, higher doses (100 vs. $200 \mathrm{mg} / \mathrm{kg} / 24 \mathrm{~h}$ amoxicillin) and shorter treatment interval $(100 \mathrm{mg} / \mathrm{kg}$ amoxicillin every $12 \mathrm{~h}$ vs. every $24 \mathrm{~h}$ ) was tested, starting $16 \mathrm{~h}$ post-inoculation. To determine the effect of additional gentamicin, $20 \mathrm{mg} / \mathrm{kg} / 24 \mathrm{~h}$ of gentamicin was administered concomitant to $100 \mathrm{mg} / \mathrm{kg} / 24 \mathrm{~h}$ amoxicillin $16 \mathrm{~h}$ post-inoculation compared to $100 \mathrm{mg} / \mathrm{kg} / 24 \mathrm{~h}$ amoxicillin only in mice who were inoculated with $10^{8} \mathrm{CFU} / \mathrm{ml}$. In the time point treatment experiments, mice were inoculated with $10^{9} \mathrm{CFU} / \mathrm{ml}$ L. monocytogenes ST1 or ST6 per strain. Twelve mice were sacrificed $16 \mathrm{~h}$ after infection, and 12 mice were treated with $100 \mathrm{mg} / \mathrm{kg}$ amoxicillin i.p. $16 \mathrm{~h}$ after infection and sacrificed after $24 \mathrm{~h}$.

\section{Scoring, harvesting, and cytokine analyses}

Clinical scoring was performed by two observers according to a previously developed scoring list for a pneumococcal meningitis mouse model (Table 1) [28]. Each scoring parameter ranges from zero, corresponding to no abnormalities, to a variable maximum score. Animals reaching humane endpoint (HEP) criteria were humanely killed. After anesthetizing the mice, cardiac 
Table 1 Clinical scoring list for bacterial meningitis mouse model

\begin{tabular}{|c|c|c|c|}
\hline Parameter & Value & $\begin{array}{l}\text { Weighted } \\
\text { score }\end{array}$ & $\begin{array}{l}\text { Max. } \\
\text { score }\end{array}$ \\
\hline \multirow[t]{5}{*}{ Weight loss } & Normal 5\% & 0 & \\
\hline & $5-10 \%$ & 1 & \\
\hline & $10-15 \%$ & 2 & \\
\hline & $15-20 \%$ & 3 & \\
\hline & $20-25 \%$ & 4 & 4 \\
\hline \multirow[t]{5}{*}{ Activity } & Normal & 0 & \\
\hline & Increased/aggressive & 1 & \\
\hline & Mildly diminished & 1 & \\
\hline & Diminished & 2 & \\
\hline & Severely diminished & 3 & 3 \\
\hline \multirow[t]{4}{*}{ Condition } & Normal, does not lay on back & 0 & \\
\hline & Upright within $5 \mathrm{~s}$ & 2 & \\
\hline & Upright within $30 \mathrm{~s}$ & 4 & \\
\hline & Does not turn upright & 6 & 6 \\
\hline \multirow[t]{4}{*}{ Coat } & Normal & 0 & \\
\hline & Diminished grooming & 1 & \\
\hline & Soiled & 1 & \\
\hline & Piloerection & 1 & 3 \\
\hline \multirow[t]{3}{*}{ Posture } & Normal & 0 & \\
\hline & Slightly hunched back & 1 & 2 \\
\hline & Severe hunched back & 2 & \\
\hline \multirow[t]{4}{*}{ Eyes } & Normal & 0 & \\
\hline & Protruding & 1 & \\
\hline & Closed eyelids & 1 & \\
\hline & Discharge & 1 & 4 \\
\hline \multirow{5}{*}{$\begin{array}{l}\text { Respiration rate } \\
\text { (per min) }\end{array}$} & $>150$ & 0 & \\
\hline & $100-150$ & 1 & \\
\hline & $75-100$ & 2 & \\
\hline & $50-75$ & 3 & \\
\hline & $<50$ & 4 & 4 \\
\hline \multirow[t]{2}{*}{ Breathing } & Irregular & 2 & \\
\hline & Labored & 2 & 4 \\
\hline \multirow{5}{*}{$\begin{array}{l}\text { Neurological } \\
\text { examination }\end{array}$} & Normal & 0 & \\
\hline & Coordination problem & 2 & \\
\hline & Paresis/paralysis & 2 & \\
\hline & Epileptic seizure & 2 & \\
\hline & Status epilepticus & 6 & 10 \\
\hline \multirow[t]{5}{*}{ Humane endpoints } & Total score $\geq 15$ & & \\
\hline & Status epilepticus & & \\
\hline & $\geq 2$ seizures in $15 \mathrm{~min}$ & & \\
\hline & Hemiparalysis & & \\
\hline & $\geq 25 \%$ weight loss & & \\
\hline
\end{tabular}

puncture was performed for blood collection, and intracisternal puncture for CSF collection. Brain, spleen, liver, and lungs were harvested and processed as described previously [28]. Supernatant, plasma, and CSF were stored at $-80{ }^{\circ} \mathrm{C}$ until further use. Cytokine analyses were performed using Luminex technology Bio-plex Pro Mouse Cytokine 6-plex Assay (Bio-Rad Laboratories, Veenendaal, the Netherlands). We analyzed levels of IL-1 $\beta$, IL-6, IL-10, IL-17A, TNF- $\alpha$, and IFN- $\gamma$ to include early and late pro- and anti-inflammatory cytokines. For cytokine values below the lower limit of detection (LLOD), the LLOD was used in the calculation of median and interquartile range. Histopathology was performed on the left hemisphere of the brain. Brain was fixed in $4 \%$ paraformaldehyde and paraffin embedded in seven coronal plaques. In all mice, a hematoxylin and eosin ( $\mathrm{H}$ and $\mathrm{E})$ staining and Gram staining were performed. Histopathology was scored (blinded) in six categories by a neuropathologist as previously described. An additional table shows this in more detail (Additional file 1) [29].

Comparison of survival curves between groups within each model was calculated using the log-rank test. Clinical scores were compared using a linear mixed model, assuming an exponential and group-specific time effect. Comparisons of cytokine levels between groups were calculated using the Mann-Whitney U test, and for dichotomous variables in histopathology scoring, the Fisher's exact test was used. All statistical tests were two-tailed, and a $p$ value of $<0.05$ was considered to be significant.

\section{Results}

Non-treatment model

In the survival study, mice inoculated with $10^{5}, 10^{6}$ and $10^{7} \mathrm{CFU} / \mathrm{ml}$ L. monocytogenes ST1 showed minimal clinical signs of disease limited to diminished grooming and/ or a slightly hunched back. They had to be sacrificed based on weight loss, $\geq 25 \%$ according to the predefined endpoint in the clinical scoring (Fig. 1a), and therefore considered not representable for a listerial meningitis model. Mice inoculated with $10^{8} \mathrm{CFU} / \mathrm{ml} \mathrm{L}$. monocytogenes ST1 showed signs of illness $12 \mathrm{~h}$ after inoculation, consisting of discharge in eyes, a slightly hunched back, mildly diminished activity and/or piloerection (median clinical score of 2; interquartile range [IQR 2-2]), and had a median survival time of $46 \mathrm{~h}$ (IQR 34-52 h; Fig. 1b). Mice inoculated with $10^{9} \mathrm{CFU} / \mathrm{ml} \mathrm{L}$. monocytogenes ST1 had signs of illness $12 \mathrm{~h}$ after inoculation (median clinical score of 3 [IQR 3-4]), and a median survival time of $40 \mathrm{~h}$ (IQR 23-46 h). The concentration of $10^{8} \mathrm{CFU} / \mathrm{ml}$ was determined to be the optimal inoculum size for the non-treatment model. There was no difference in male or female mice in survival. An additional figure shows this in more detail (Additional file 2). 


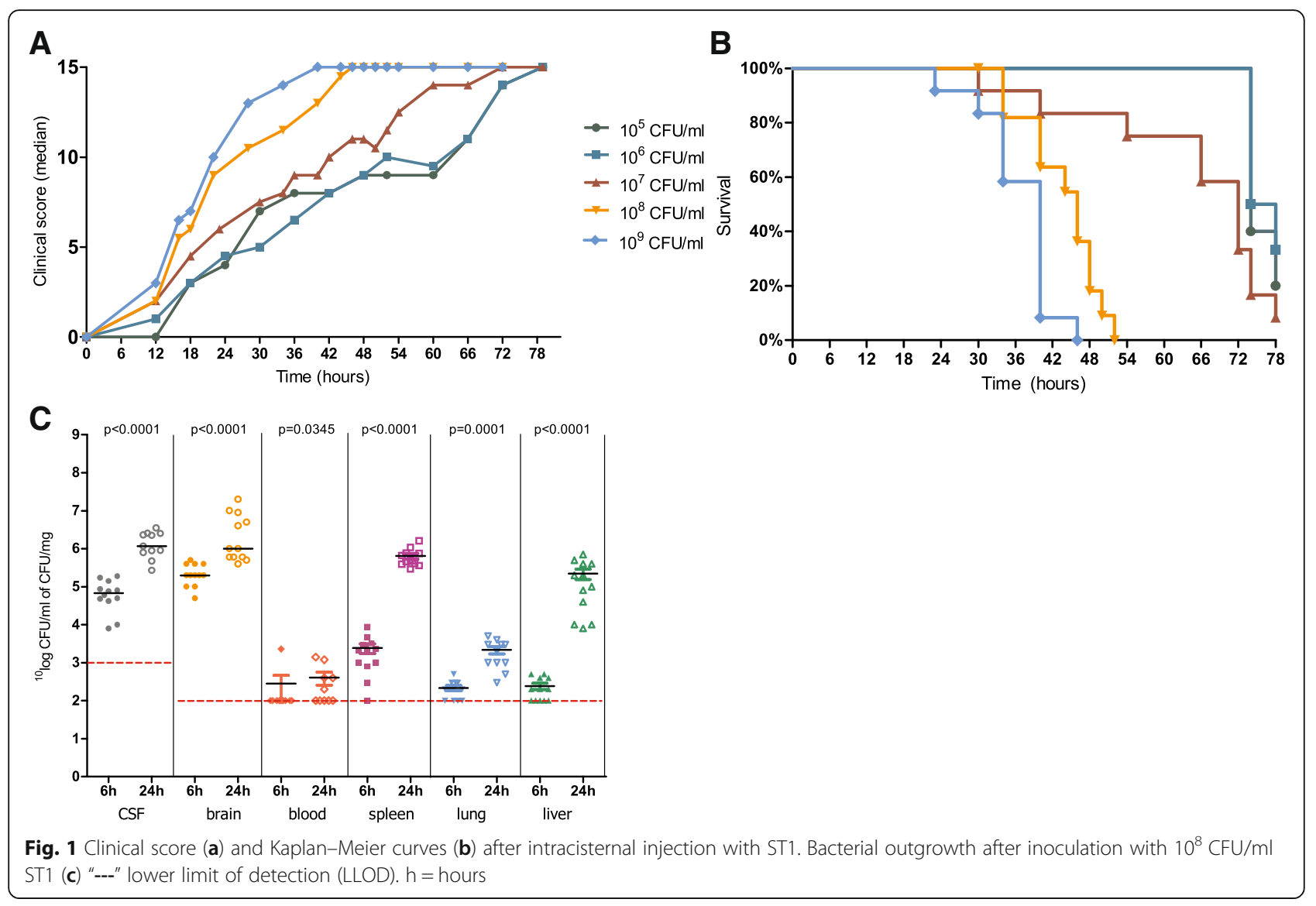

After intracisternal injection of $10^{8} \mathrm{CFU} / \mathrm{ml}$ L. monocytogenes ST1, CFUs increased significantly over time in CSF, blood, and collected organs (Fig. 1c). Median L. monocytogenes concentration in the CSF was $6.8 \times$ $10^{4} \mathrm{CFU}$ after $6 \mathrm{~h}$ and $1.2 \times 10^{6} \mathrm{CFU} / \mathrm{ml}$ after $24 \mathrm{~h}$. In the brain homogenates, median titres were $2.0 \times 10^{5}$ after $6 \mathrm{~h}$ and $1.0 \times 10^{6} \mathrm{CFU} / \mathrm{mg}$ after $24 \mathrm{~h}$. In the spleen, lungs, and liver homogenates, median bacterial titres were $2.1 \times 10^{3}$, $2.0 \times 10^{2}$, and $2.0 \times 10^{2} \mathrm{CFU} / \mathrm{mg}$ after $6 \mathrm{~h}$ and $4.9 \times 10^{5}$, $2.0 \times 10^{3}$, and $1.5 \times 10^{5} \mathrm{CFU} / \mathrm{mg}$ after $24 \mathrm{~h}$ respectively. Median titre in blood at $6 \mathrm{~h}$ was under the LLOD $(<1.0 \times$ $10^{2} \mathrm{CFU} / \mathrm{ml}$ ) and $1.5 \times 10^{2} \mathrm{CFU} / \mathrm{ml}$ after $24 \mathrm{~h}$.

Luminex analyses showed similar cytokine levels in the brain at the 6-h time point compared to negative controls, except for IL-1 $\beta$ in which levels were lower compared to the controls. Levels of IL-6, IL-17A, and IFN- $\gamma$ were elevated in brain homogenates at the 24-h time point in infected mice compared to controls (Fig. 2), and all increased after $24 \mathrm{~h}$ compared to the 6 -h time point. Plasma levels of all measured cytokines with the exception of IL-17A were elevated at both time points compared to the controls, and IL-6, IL-10, and IFN- $\gamma$ increased between $6 \mathrm{~h}$ and $24 \mathrm{~h}$ (Fig. 2).

Histopathology showed increased brain damage between $t=6$ and $t=24$ in the non-treatment model.
Median pathology score increased from 2 [IQR 1-4] to 7 [IQR 6-9] ( $p=0.001$, an additional table shows this in more detail Additional file 3) due to increase from mild focal meningeal infiltration (Fig. 3a) to severe meningeal infiltration (Fig. 3b), and meningeal vascular inflammation from one mouse (8\%) $6 \mathrm{~h}$ post-inoculation to 12 mice $(100 \%) 24 \mathrm{~h}$ post-inoculation. Focal small parenchymal and subarachnoid bleedings were present in 6 of 12 mice at $6 \mathrm{~h} \mathrm{(50 \% ),} \mathrm{and} \mathrm{developed} \mathrm{into} \mathrm{multiple} \mathrm{paren-}$ chymal and subarachnoid hemorrhages at $24 \mathrm{~h}$ (in 58\%, Fig. 3c). Ventriculitis was present in $17 \%$ of mice at $6 \mathrm{~h}$ to $42 \%$ at $24 \mathrm{~h}$.

\section{Treatment model}

Treatment time point was chosen at $16 \mathrm{~h}$ post-infection based on clinical course of disease in the survival experiments in mice inoculated with $10^{9} \mathrm{CFU} / \mathrm{ml}$ bacteria. Treatment with $100 \mathrm{mg} / \mathrm{kg} / 24 \mathrm{~h}$ of amoxicillin was superior to $50 \mathrm{mg} / \mathrm{kg} / 24 \mathrm{~h}$ of amoxicillin in survival (median survival $70 \mathrm{~h}$ vs. $46 \mathrm{~h}, p<0.001$; an additional figure shows this in more detail Additional file 4a). Further experiments showed survival did not improve by treating mice with $200 \mathrm{mg} / \mathrm{kg} / 24 \mathrm{~h}$ or $100 \mathrm{mg} / \mathrm{kg} / 12 \mathrm{~h}$ of amoxicillin or adjuvant $20 \mathrm{mg} / \mathrm{kg} / 24 \mathrm{~h}$ of gentamicin compared to $100 \mathrm{mg} / \mathrm{kg} / 24 \mathrm{~h}$ of amoxicillin, and no 


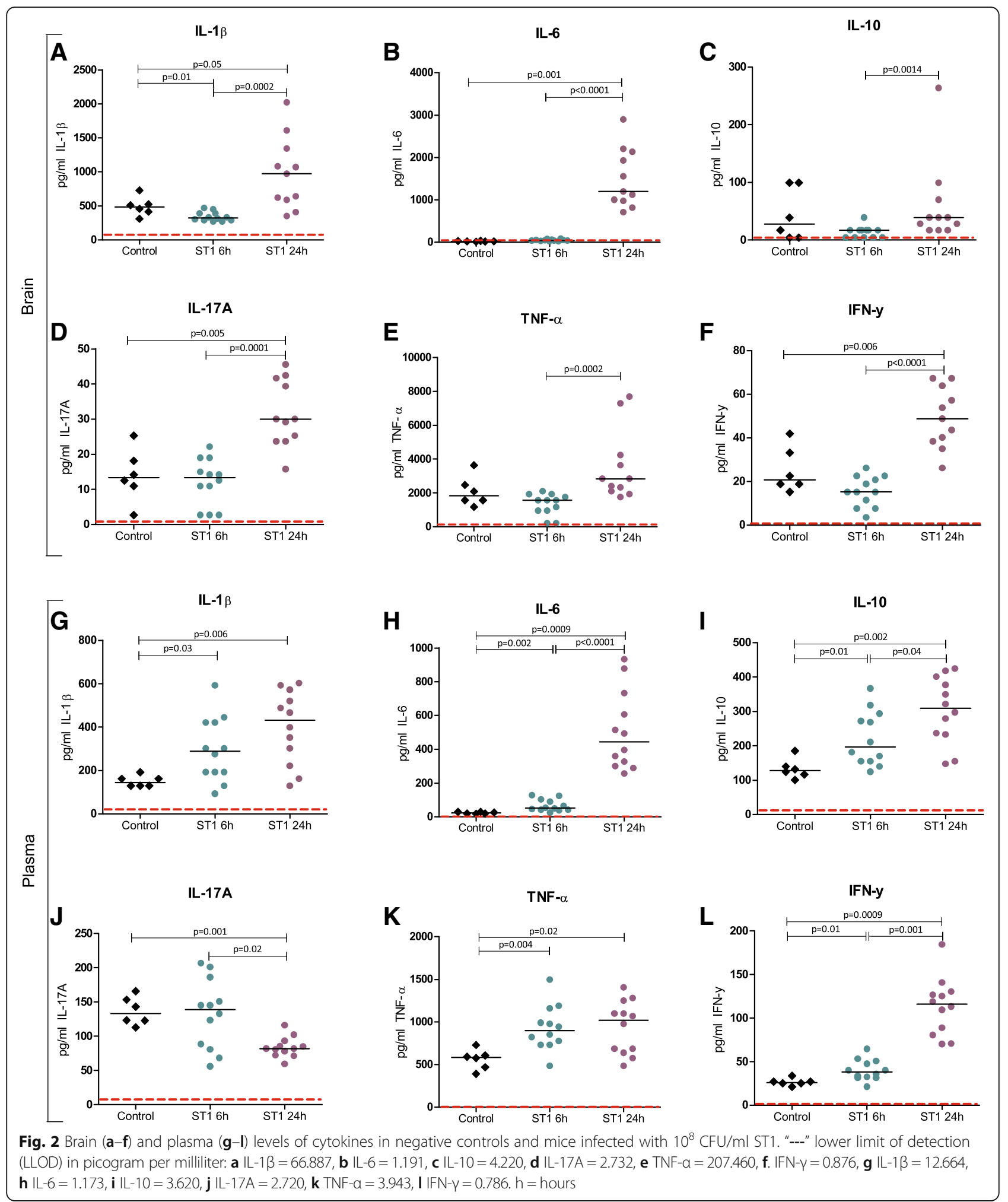

significant differences were found in clinical scoring (Additional files 2 and 4). In all survival experiments, brain homogenates from mice that survived till the end of the experiment (70 $\mathrm{h}$ post-inoculation) showed bacterial outgrowth. Decreasing the inoculum size to $10^{8} \mathrm{CFU} / \mathrm{ml}$ did not improve clearance of bacteria. An additional table shows this in more detail (Additional file 5). 


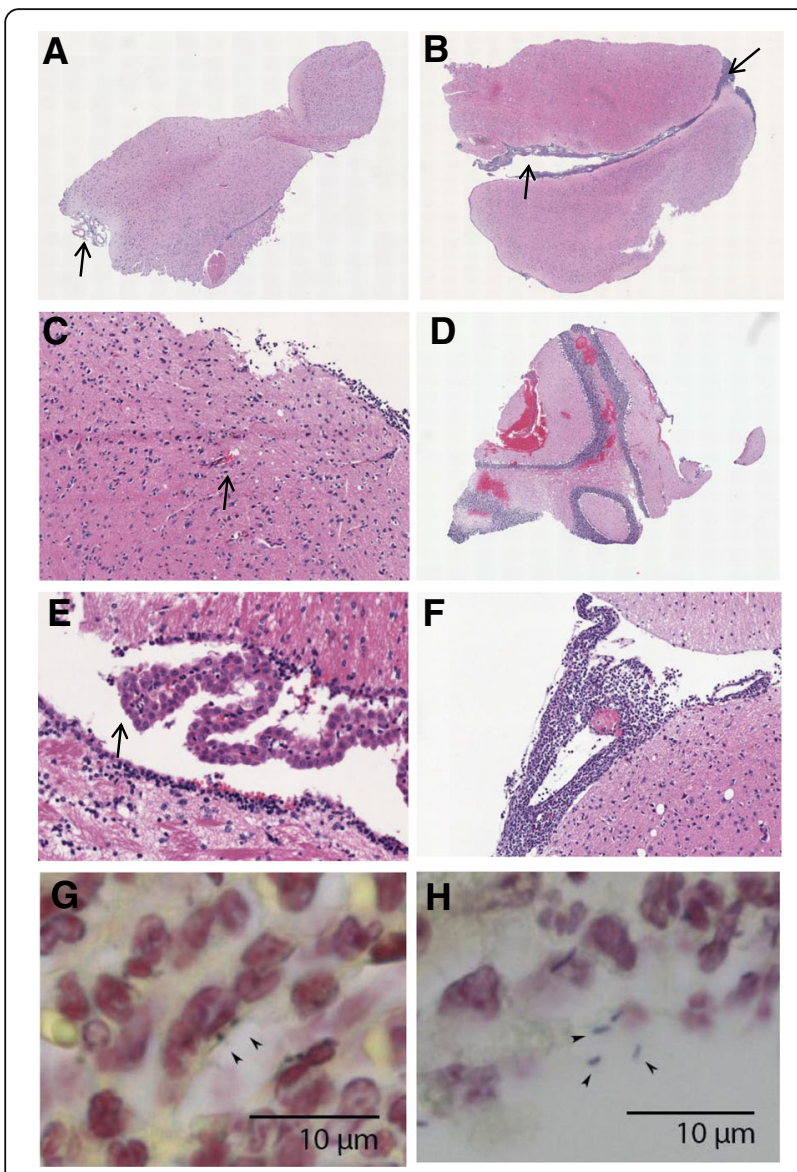

Fig. 3 Histopathology in listerial meningitis mice model. Mild meningeal infiltration (a, score 1), severe meningeal infiltration (b, score 3), focal and meningeal bleeding (c, score 1), bleeding (d, score 3 ) ventriculitis (e, score 3), focal thrombosis (f, score 1). Gram staining of meninges demonstrating intra-(g) and extracellular (h) bacteria

In the time point study, bacterial titres in all collected fluids and organs decreased between $16 \mathrm{~h}$ and $24 \mathrm{~h}$ after treatment with $100 \mathrm{mg} / \mathrm{kg} / 24 \mathrm{~h}$ of amoxicillin. Sixteen hours post-inoculation median bacterial titre in CSF was $4.3 \times 10^{6} \mathrm{CFU} / \mathrm{ml}$, and decreased after treatment with amoxicillin to $5.2 \times 10^{5} \mathrm{CFU} / \mathrm{ml}$ at $24 \mathrm{~h}$. An additional figure shows this in more detail (Additional file 4). Median bacterial concentration in the brain homogenates was $6.4 \times 10^{7}$ after $16 \mathrm{~h}$ and $1.0 \times 10^{6} \mathrm{CFU} / \mathrm{mg}$ after $24 \mathrm{~h}$, and in blood, spleen, lungs, and liver homogenates, median bacterial titres were $2.0 \times 10^{3}, 3.3 \times 10^{6}, 8.2 \times$ $10^{3}$, and $4.1 \times 10^{4} \mathrm{CFU} / \mathrm{mg}$ after $16 \mathrm{~h}$ and $1.6 \times 10^{2}$, $1.3 \times 10^{5}, 2.3 \times 10^{3}$, and $2.2 \times 10^{4} \mathrm{CFU} / \mathrm{mg}$ after $24 \mathrm{~h}$ respectively.

Cytokine measurements showed elevated IL-1 $\beta$, IL-6, and IL-17A concentration in ST1-infected mice compared to negative controls in both time points (Fig. 4). Luminex of plasma in the treatment model showed elevated levels of IL- 6 , IL-10, and IFN- $\gamma$ and decreased levels of IL-17A at both time points. IL-1 $\beta$ was elevated at the 16-h time point in ST1-infected mice compared to controls (Fig. 4).

Overall, histopathological score was similar between 16and 24-h time points (median score 7 [IQR 5-8] vs. 9 [IQR 8-12]). An additional table shows this in more detail (Additional file 3). Meningeal infiltration and meningeal vascular inflammation were present in all mice. As seen in the non-treatment model, bleeding and ventriculitis were frequently present. Hemorrhages were found parenchymal or subarachnoidal, and were categorized as small and focal, $16 \mathrm{~h}$ post-inoculation in $73 \%$ of mice and as large hemorrhages at multiple locations in $91 \%$ after $24 \mathrm{~h}$.

\section{Bacterial strain ST1 vs. ST6}

In the non-treatment time point experiments, clinical score and bacterial outgrowth of ST6 in CSF, blood, and collected organs were comparable to ST1. Cytokine and chemokine levels in brain homogenates measured at similar time points did not differ between ST1 and ST6. In plasma, IL-1 $\beta$ and TNF- $\alpha$ of both STs were significantly elevated $6 \mathrm{~h}$ post-inoculation, and ST1 $24 \mathrm{~h}$ post-inoculation compared to the negative controls. At $t$ $=24$, there was a significant difference between strains in median IL-1 $\beta$ levels, ST1 $432 \mathrm{pg} / \mathrm{ml}$ [IQR 282$533 \mathrm{pg} / \mathrm{ml}$ ] and ST6 $192 \mathrm{pg} / \mathrm{ml}$ [IQR 137-307 pg/ml] $(p$ $=0.04)$, and at both time points, there was a significant difference in TNF- $\alpha$ levels between ST1 and ST6 (TNF- $\alpha t=6$; ST1 $900 \mathrm{pg} / \mathrm{ml}$ [IQR 766-1034] vs. ST6 $746 \mathrm{pg} / \mathrm{ml}$ [IQR 639-812] $(p=0.03)$ and at $t=24 ; \mathrm{ST} 1$ $1022 \mathrm{pg} / \mathrm{ml}$ [IQR 674-1137] vs. $470 \mathrm{pg} / \mathrm{ml}$ [IQR 370746], $p=0.045)$. Histopathology scores in ST1- and ST6-infected mice were similar in terms of meningeal infiltration, severity of ventriculitis, thrombosis, and increase of meningeal vascular inflammation over time. Six hours post-inoculation, focal small parenchymal and meningeal bleeding was present in 6 of 12 ST1 mice (50\%), while it was only seen in one of the 12 ST6-infected mice $(8 \%, p=$ $0.03)$, but overall pathology scores were similar between ST1- and ST6-infected mice at $24 \mathrm{~h}$.

There were no significant differences in clinical score and bacterial outgrowth in collected fluids or organs between ST1 and ST6 in both non-treatment and treatment model. An additional figure shows this in more detail (Additional file 6). In the treatment model, five ST6 mice had to be euthanized (three because of puncture failure and two because of wounds after fighting). However, brain levels of IL-6, IL17A, TNF- $\alpha$, and IFN- $\gamma$ in ST1-inoculated mice compared to ST6 $16 \mathrm{~h}$. An additional table shows this in more detail (Additional file 7). In plasma, IL-1 $\beta$ levels were higher in ST1-inoculated mice at both time points compared to ST6-infected mice, and IL-10 and TNF- $\alpha$ levels were higher at the 24-h time point in ST1-infected mice. Overall pathology score was higher at $24 \mathrm{~h}$ in ST1-infected mice (median 


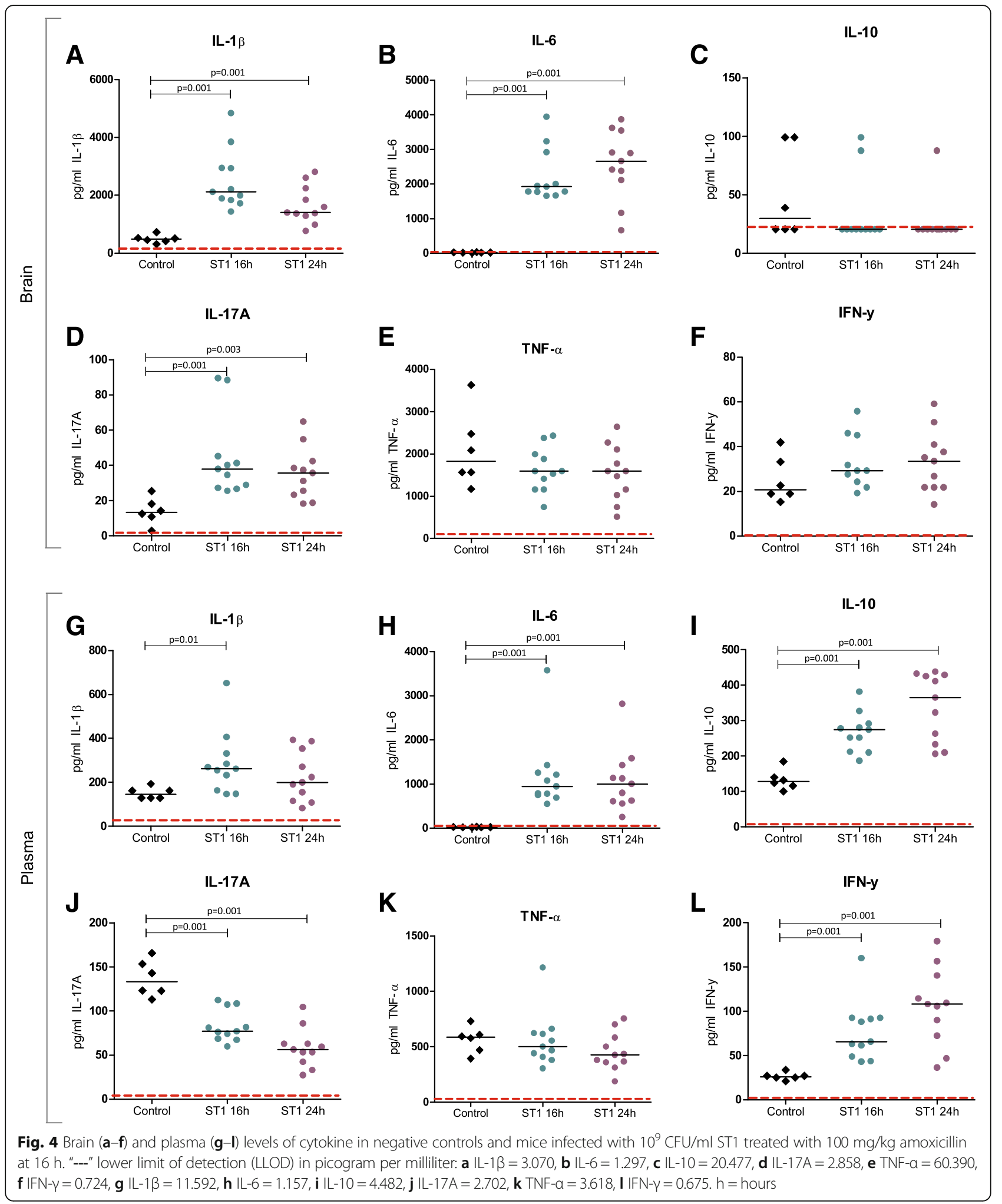

score 9; [8-11, 31]) compared to ST6-inoculated mice (median score 7; [6, 7], $p=0.002$ ). This was mainly driven by increased meningeal infiltration, ventriculitis, and hemorrhages in ST1-infected mice.

\section{Discussion}

We developed and validated a murine model of listerial meningitis. We used Listeria sequence types [18, 32] that commonly cause invasive disease [18, 31]. Previously 
described intracisternally inoculation mice and rat studies used a serotype $4 \mathrm{~b}$ strain with unknown sequence type [24-26]; intracerebral inoculation mice studies [22, 23] used a less virulent laboratory EGD strain compared to the ST1 and ST6 strains [18, 33]. We used intracisternal inoculation aiming for a reproducible meningitis model. Previous studies using oral and intravenous inoculation reported difficulties with respect to neuro-invasion reproducibility [15-17, 34-36], while intracerebral injection primarily causes cerebritis. Intracerebral inoculation methods have been used successfully previously to study the role of macrophage inflammatory protein and TNF- $\alpha$ in listerial meningitis [22, 23]. Intracisternal inoculation has been used to study heat production [24], compare effectiveness of antibiotics [26], and the role of reactive oxygen and nitric oxide in listeria growth [25]. Our model allows evaluation of multiple features including bacterial growth, host immune response, clinical severity, and histopathological damage.

Main histopathological characteristics of listerial meningitis were meningeal inflammation, ventriculitis, and abscesses. This is in line with previous studies [37, 38]. We also observed a high rate of cerebral hemorrhages, an uncommon feature in human listerial meningitis $(2 \%$ of cases) [10]. This is consistent with the observed difference in pneumococcal meningitis in a human and mouse model [28, 39]. In human bacterial meningitis, it has been suggested that dysregulation of coagulation and fibrinolytic pathways, vascular endothelial cell swelling, and vasculitis plays a role in the pathophysiology of hemorrhages [40-44].

IL-1 $\beta$, IL-6, IL-10, IL-17A, TNF- $\alpha$, and IFN- $\gamma$ mediated the hosts immune response against $L$. monocytogenes. Previous listerial mouse models showed that monocyte recruitment to the brain is triggered by pro-inflammatory cytokines in particular IFN- $\gamma-$, TNF- , and IL-6-related immune response $[45,46]$. These cytokines and IL-1 $\beta$ and IL-17A are able to mobilize phagocytes and activate other cytokines [11-14, 46-54], whereas IL-10 limits the immune-mediated injury; nonetheless can increase severity of $L$. monocytogenes disease by reducing the immune response [55-57]. Since IL-6 and IFN- $\gamma$ were elevated in the brain and blood of both our treatment and non-treatment mouse models, these cytokines are relevant outcome measures in our model to study changes in the inflammatory response. An interesting aspect of IFN- $\gamma$ is its ambiguous role in listerial infections. It is known for its protective and controlling role in the early immune response, though it seems to promote susceptibility for L. monocytogenes later on. Study models with interferon-deficient mice showed protective effects during systemic listerial infections [58-60]. In CSF of patients with listerial meningitis, elevation of IFN- $\gamma$, IFN- $\alpha 2$, and interferon-related cytokines
IL-18, CX3CL1, and CCL20 were associated with an unfavorable outcome [61]. The use of amoxicillin, a bacteriolytic antibiotic, in our model did not lead to a significant increase in cytokine levels after therapy, as observed in other experimental models of bacterial meningitis also using bacteriolytic antibiotic.

Infection with Listeria strain of the ST1 type led to a more rigorous inflammatory response and more brain damage as compared to infection with ST6. Both STs have been marked as hypervirulent strains with a tropism for neuro-invasion [18]. ST1 has been among the most common genotypes causing listerial meningitis in the Netherlands over the last 25 years [31]. ST6 has been emerging over the last years and has been associated with an increasing rate of unfavorable outcome among adults with listerial meningitis, from 27 to $61 \%$ over a 14-year period [10]. The increased incidence of ST6 listerial meningitis in the Netherlands has been associated with the introduction of a novel plasmid, carrying the efflux transporter emrC [62]. Although speculative, differences in virulence between ST1 and ST6 found in our model could be explained by (i) degree of cell-to-cell spread from infected phagocytes to endothelial cells $[63,64]$; (ii) the interaction with macrophages, neutrophils, and subsequently the cytokine signaling [65]; (iii) the proportion of Listeria bacteria residing in the brain parenchyma rather than extracellularly in the CSF, and thereby causing different degrees of histopathological damage [66]; (iv) degree of expression of the specific neuro-invasive internalin InlF and its binding to the filament protein vimentin $[67,68]$; (v) presence of certain genetic elements in the bacteria such as LIPI-3 (in both ST1 and ST6) [69], LGI 2 (found in ST1) [70], or pLMST6 (found in ST6) [62]; (vi) other yet unknown factors influencing and differentiating the virulence of L. monocytogenes strains. Since ST1 and ST6 are clinically relevant strains, these unknown factors should be investigated and might help to unravel the pathophysiology of L. monocytogenes.

Our model has several limitations, of which some are inherent to the use of modeling of human disease in animals. First, we infected mice by inoculating directly into the cisterna magna, while the route of infection in humans mainly is through the digestive system. However, meningitis is difficult to evoke unless bacteria are injected directly intracranial, partially because animals tend to die due to systemic illness before meningitis develops [71]. Furthermore, the amount of bacteria reaching the brain cannot be controlled using digestive tract or intravenous inoculation. Second, in the treatment survival experiments, we observed that Listeria could be cultured from the murine brains despite high doses antibiotic treatment. This can be explained as the pathogen is intracellular and has a relatively slow growth rate. 
Patients with listerial meningitis are therefore treated for at least 3 weeks. To make sure we did not use insufficient dosage or type of antibiotics, we increased the dose and frequency of the amoxicillin and added gentamycin, but these changes did not influence outcome or bacterial outgrowth at the end of the experiment. Therefore, we feel that we achieved an optimal amoxicillin dose to perform the experiments with. We did observe that bacterial counts decreased in all treated mice. It could be argued that other antibiotics with a previously suggested effect and/or had a synergism in treatment of listerial meningitis should have been tested [30]. However, amoxicillin with or without gentamicin is the most commonly used treatment in human listerial meningitis, and therefore testing other antibiotics is beyond the scope of this article.

\section{Conclusions}

The listerial meningitis mouse model provides an experimental setting of listerial meningitis with multiple outcome parameters. Similar model set up in pneumococcal meningitis has proven to be useful in exploring inflammatory hypotheses in pneumococcal meningitis [72-74]. Integration of these pathological features in a single model is a valuable tool in the further investigation of both pathophysiological and therapeutic intervention studies in listerial meningitis.

\section{Additional files}

Additional file 1: This table shows a histopathological scoring method of brain tissue in bacterial meningitis mouse model which has been used in this study and previously has been used in a pneumococcal meningitis model. (DOC $48 \mathrm{~kb}$ )

Additional file 2: Kaplan-Meier survival curve (A) in male and female mice (24 mice/group). Clinical score of the treatment survival experiments (12 mice/ group) inoculated with $10^{9}$ CFU bacteria and treated with antibiotics. Abbreviation; $h=$ hours (PDF $30 \mathrm{~kb}$ )

Additional file 3: This table shows histopathological scoring of brain tissue in listerial meningitis time point studies with L. monocytogenes ST1 and ST6 strains. Results are presented based on number of mice and on median pathology score. (DOC $82 \mathrm{~kb}$ )

Additional file 4: Kaplan-Meier survival curves in treatment survival experiments inoculated with $10^{9} \mathrm{CFU} / \mathrm{ml}\left(\mathrm{A}\right.$ and $\mathrm{B}$ ) and with $10^{8} \mathrm{CFU} / \mathrm{ml}(\mathrm{C})$ and bacterial outgrowth after inoculation with $10^{9} \mathrm{CFU} / \mathrm{ml}$ L. monocytogenes ST1 and amoxicillin treatment (D). --- lower limit of detection, Abbreviation; $h=$ hours. (PDF $44 \mathrm{~kb}$ )

Additional file 5: This table shows bacterial outgrowth in brain homogenate in mice infected with L. monocytogenes ST1 and treated with antibiotics during survival experiments (70 h post inoculation). Every bacterial count represents one mouse. (DOC $51 \mathrm{~kb}$ )

Additional file 6: (A) Median clinical score in ST1 and ST6 inoculated mice in the non-treatment model with interquartile ranges, (B) Bacterial outgrowth in the non-treatment model ST1 vs. ST6 $6 \mathrm{~h}$ after inoculation. Titres are expressed per mice and with median CFU/ml or CFU/mg. (PDF $38 \mathrm{~kb}$ )

Additional file 7: This table shows the brain and plasma levels of cytokines in mice infected with $10^{9} \mathrm{CFU} / \mathrm{ml}$ L. monocytogenes ST1 or ST6 at time points 16 and $24 \mathrm{~h}$ and treated with $100 \mathrm{mg} / \mathrm{kg} / 24 \mathrm{~h}$ amoxicillin after $16 \mathrm{~h}$. (DOC $64 \mathrm{~kb})$

\section{Abbreviations}

ARRIVE: Animal Research: Reporting of In Vivo Experiments; CC: Clonal complex; CFU: Colony forming units; CSF: Cerebrospinal fluid; $\mathrm{H}$ and $\mathrm{E}$ : Hematoxylin and eosin staining; HEP: Humane endpoint; i.p.: Intraperitoneal; IQR: Interquartile range; LD50: Lethal dose for 50\% of mice; LLOD: Lower limit of detection; NRLBM: Netherlands Reference Laboratory for Bacterial Meningitis; OD: Optical density; ST1: Sequence type 1

\section{Funding}

This study was supported by the Netherlands Organization for Health Research and Development (ZonMw; NWO-Veni-Grant [916.13.078] to MB, NWO-Vidi-Grant [016.116.358] to DB), the Academic Medical Center (AMC Fellowship to DB), and the European Research Council (ERC Starting Grant to DB).

\section{Availability of data and materials}

Data of the MeninGene study is available for all researchers at www.MeninGene.eu.

\section{Authors' contributions}

MMK, JYEL, VJ, and WKM substantially contributed to conception and design, acquisition of data, analysis and interpretation of data, drafted the manuscript, and final approval of the version to be published. MCB, MVS, and DvdB substantially contributed to conception and design, acquisition of data, analysis and interpretation of data, revised the manuscript for important intellectual content, and final approval of the version to be published. All authors read and approved the final manuscript.

\section{Ethics approval}

The study was approved by the Medical Ethical Committee of the Academic Medical Centre, Amsterdam, the Netherlands. Experiments were approved by the Institutional Animal Care and Use Committee of the Academic Medical Center, Amsterdam, the Netherlands.

\section{Consent for publication}

Not applicable.

\section{Competing interests}

The authors declare that they have no competing interests.

\section{Publisher's Note}

Springer Nature remains neutral with regard to jurisdictional claims in published maps and institutional affiliations.

Received: 7 June 2018 Accepted: 28 August 2018

Published online: 07 September 2018

\section{References}

1. van de Beek D, de Gans J, Spanjaard L, Weisfelt M, Reitsma JB, Vermeulen M. Clinical features and prognostic factors in adults with bacterial meningitis. N Engl J Med. 2004;351:1849-59.

2. Bijlsma MW, Brouwer MC, Kasanmoentalib ES, Kloek AT, Lucas MJ, Tanck MW, van der Ende A, van de Beek D. Community-acquired bacterial meningitis in adults in the Netherlands, 2006-14: a prospective cohort study. Lancet Infect Dis. 2016;16:339-47.

3. Moon SY, Chung DR, Kim SW, Chang HH, Lee H, Jung DS, Kim YS, Jung SI, Ryu SY, Heo ST, et al. Changing etiology of community-acquired bacterial meningitis in adults: a nationwide multicenter study in Korea. Eur J Clin Microbiol Infect Dis. 2010;29:793-800.

4. Thigpen MC, Whitney CG, Messonnier NE, Zell ER, Lynfield R, Hadler JL, Harrison LH, Farley MM, Reingold A, Bennett NM, et al. Bacterial meningitis in the United States, 1998-2007. N Engl J Med. 2011;364:2016-25.

5. Vivant AL, Garmyn D, Piveteau P. Listeria monocytogenes, a down-to-earth pathogen. Front Cell Infect Microbiol. 2013;3:87.

6. Stea EC, Purdue LM, Jamieson RC, Yost CK, Truelstrup Hansen L. Comparison of the prevalences and diversities of listeria species and listeria monocytogenes in an urban and a rural agricultural watershed. Appl Environ Microbiol. 2015;81:3812-22.

7. Charlier C, Perrodeau E, Leclerca A, Cazenave B, Pilmis B, Henry B, Lopes A, Maury MM, Moura A, Goffinet F, et al. Clinical features and prognostic 
factors of listeriosis: the MONALISA national prospective cohort study. Lancet Infect Dis. 2017;15:150-9.

8. van Ettekoven CN, van de Beek D, Brouwer MC. Update on communityacquired bacterial meningitis: guidance and challenges. Clin Microbiol Infect. 2017;23:601-6.

9. van Veen $\mathrm{KEB}$, Brouwer MC, van der Ende A, van de Beek D. Bacterial meningitis in patients using immunosuppressive medication: a population-based prospective nationwide study. J Neurolmmune Pharmacol. 2017;12:213-8.

10. Koopmans MM, Brouwer MC, Bijlsma MW, Bovenkerk S, Keijzers W, van der Ende A, van de Beek D. Listeria monocytogenes sequence type 6 and increased rate of unfavorable outcome in meningitis: epidemiologic cohort study. Clin Infect Dis. 2013;57:247-53.

11. Labow M, Shuster D, Zetterstrom M, Nunes P, Terry R, Cullinan EB, Bartfai T, Solorzano C, Moldawer LL, Chizzonite R, Mclntyre KW. Absence of IL-1 signaling and reduced inflammatory response in IL-1 type I receptordeficient mice. J Immunol. 1997;159:2452-61.

12. Dalrymple SA, Lucian LA, Slattery R, McNeil T, Aud DM, Fuchino S, Lee F, Murray R. Interleukin-6-deficient mice are highly susceptible to listeria monocytogenes infection: correlation with inefficient neutrophilia. Infect Immun. 1995;63:2262-8.

13. Tripp CS, Gately MK, Hakimi J, Ling P, Unanue ER. Neutralization of IL-12 decreases resistance to listeria in SCID and C.B-17 mice. Reversal by IFNgamma. J Immunol. 1994;152:1883-7.

14. Tripp CS, Wolf SF, Unanue ER. Interleukin 12 and tumor necrosis factor alpha are costimulators of interferon gamma production by natural killer cells in severe combined immunodeficiency mice with listeriosis, and interleukin 10 is a physiologic antagonist. Proc Natl Acad Sci U S A. 1993;90: 3725-9.

15. Czuprynski CJ, Faith NG, Steinberg H. A/J mice are susceptible and C57BL/6 mice are resistant to listeria monocytogenes infection by intragastric inoculation. Infect Immun. 2003;71:682-9.

16. Bou Ghanem EN, Myers-Morales T, D'Orazio SE. A mouse model of foodborne listeria monocytogenes infection. Curr Protoc Microbiol. 2013;31:9B 3 1-9B 316.

17. Bergmann S, Beard PM, Pasche B, Lienenklaus S, Weiss S, Gahan CG, Schughart K, Lengeling A. Influence of internalin A murinisation on host resistance to orally acquired listeriosis in mice. BMC Microbiol. 2013;13:90.

18. Maury MM, Tsai YH, Charlier C, Touchon M, Chenal-Francisque V, Leclercq A, Criscuolo A, Gaultier C, Roussel S, Brisabois A, et al. Uncovering listeria monocytogenes hypervirulence by harnessing its biodiversity. Nat Genet. 2016:48:308-13.

19. Virna S, Deckert M, Lutjen S, Soltek S, Foulds KE, Shen H, Korner H, Sedgwick JD, Schluter D. TNF is important for pathogen control and limits brain damage in murine cerebral listeriosis. J Immunol. 2006;177:3972-82.

20. Deckert M, Soltek S, Geginat G, Lutjen S, Montesinos-Rongen M, Hof H, Schluter D. Endogenous interleukin-10 is required for prevention of a hyperinflammatory intracerebral immune response in listeria monocytogenes meningoencephalitis. Infect Immun. 2001;69:4561-71.

21. Schluter D, Chahoud S, Lassmann H, Schumann A, Hof H, Deckert-Schluter M. Intracerebral targets and immunomodulation of murine listeria monocytogenes meningoencephalitis. J Neuropathol Exp Neurol. 1996;55: 14-24.

22. Seebach J, Bartholdi D, Frei K, Spanaus KS, Ferrero E, Widmer U, Isenmann S, Strieter RM, Schwab M, Pfister H, Fontana A. Experimental listeria meningoencephalitis. Macrophage inflammatory protein-1 alpha and -2 are produced intrathecally and mediate chemotactic activity in cerebrospinal fluid of infected mice. J Immunol. 1995;155:4367-75.

23. Leist TP, Frei K, Kam-Hansen S, Zinkernagel RM, Fontana A. Tumor necrosis factor alpha in cerebrospinal fluid during bacterial, but not viral, meningitis. Evaluation in murine model infections and in patients. J Exp Med. 1988;167: 1743-8.

24. Trampuz A, Steinhuber A, Wittwer M, Leib SL. Rapid diagnosis of experimental meningitis by bacterial heat production in cerebrospinal fluid. BMC Infect Dis. 2007;7:116.

25. Remer KA, Jungi TW, Fatzer R, Tauber MG, Leib SL. Nitric oxide is protective in listeric meningoencephalitis of rats. Infect Immun. 2001;69:4086-93.

26. Michelet C, Leib SL, Bentue-Ferrer D, Tauber MG. Comparative efficacies of antibiotics in a rat model of meningoencephalitis due to listeria monocytogenes. Antimicrob Agents Chemother. 1999;43:1651-6.

27. Kilkenny C, Browne WJ, Cuthill IC, Emerson M, Altman DG. Improving bioscience research reporting: the ARRIVE guidelines for reporting animal research. PLoS Biol. 2010;8:e1000412.
28. Mook-Kanamori B, Geldhoff M, Troost D, van der Poll T, van de Beek D. Characterization of a pneumococcal meningitis mouse model. BMC Infect Dis. 2012;12:71.

29. Engelen-Lee JY, Brouwer MC, Aronica E, van de Beek D. Pneumococcal meningitis: clinical-pathological correlations (meningene-path). Acta Neuropathol Commun. 2016:4:26.

30. van de Beek D, Cabellos C, Dzupova O, Esposito S, Klein M, Kloek AT, Leib SL, Mourvillier B, Ostergaard C, Pagliano P, et al. ESCMID guideline: diagnosis and treatment of acute bacterial meningitis. Clin Microbiol Infect. 2016; 22(Suppl 3):S37-62.

31. Koopmans MM, Bijlsma MW, Brouwer MC, van de Beek D, van der Ende A. Listeria monocytogenes meningitis in the Netherlands, 1985-2014: a nationwide surveillance study. J Inf. 2017;75:12-9.

32. Ragon M, Wirth T, Hollandt F, Lavenir R, Lecuit M, Le Monnier A, Brisse S. A new perspective on listeria monocytogenes evolution. PLoS Pathog. 2008;4: e1000146.

33. Becavin C, Bouchier C, Lechat P, Archambaud C, Creno S, Gouin E, Wu Z, Kuhbacher A, Brisse $S$, Pucciarelli MG, et al. Comparison of widely used listeria monocytogenes strains EGD, 10403S, and EGD-e highlights genomic variations underlying differences in pathogenicity. MBio. 2014;5:e00969-14.

34. Barbour AH, Rampling A, Hormaeche CE. Comparison of the infectivity of isolates of listeria monocytogenes following intragastric and intravenous inoculation in mice. Microb Pathog. 1996;20:247-53.

35. Lecuit M, Cossart P. Genetically-modified-animal models for human infections: the listeria paradigm. Trends Mol Med. 2002;8:537-42.

36. Lecuit M. Human listeriosis and animal models. Microbes Infect. 2007;9: 1216-25.

37. Uldry PA, Kuntzer T, Bogousslavsky J, Regli F, Miklossy J, Bille J, Francioli P, Janzer R. Early symptoms and outcome of listeria monocytogenes rhombencephalitis: 14 adult cases. J Neurol. 1993;240:235-42.

38. Prats N, Briones V, Blanco MM, Altimira J, Ramos JA, Dominguez L, Marco A. Choroiditis and meningitis in experimental murine infection with listeria monocytogenes. Eur J Clin Microbiol Infect Dis. 1992;11:744-7.

39. Mook-Kanamori BB, Fritz D, Brouwer MC, van der Ende A, van de Beek D. Intracerebral hemorrhages in adults with community associated bacterial meningitis in adults: should we reconsider anticoagulant therapy? PLoS One. 2012;7:e45271.

40. Winkler F, Kastenbauer S, Koedel U, Pfister HW. Role of the urokinase plasminogen activator system in patients with bacterial meningitis. Neurology. 2002;59:1350-5.

41. Mook-Kanamori BB, Geldhoff M, van der Poll T, van de Beek D. Pathogenesis and pathophysiology of pneumococcal meningitis. Clin Microbiol Rev. 2011; 24:557-91.

42. Vergouwen MD, Schut ES, Troost D, van de Beek D. Diffuse cerebral intravascular coagulation and cerebral infarction in pneumococcal meningitis. Neurocrit Care. 2010;13:217-27.

43. Kowalik MM, Smiatacz T, Hlebowicz M, Pajuro R, Trocha H. Coagulation, coma, and outcome in bacterial meningitis--an observational study of 38 adult cases. J Inf Secur. 2007:55:141-8.

44. Weisfelt M, Determann RM, de Gans J, van der Ende A, Levi M, van de Beek D, Schultz MJ. Procoagulant and fibrinolytic activity in cerebrospinal fluid from adults with bacterial meningitis. J Inf Secur. 2007;54:545-50.

45. Drevets DA, Bronze MS. Listeria monocytogenes: epidemiology, human disease, and mechanisms of brain invasion. FEMS Immunol Med Microbiol. 2008:53:151-65.

46. Havell EA, Sehgal PB. Tumor necrosis factor-independent IL-6 production during murine listeriosis. J Immunol. 1991;146:756-61.

47. Huang S, Hendriks W, Althage A, Hemmi S, Bluethmann H, Kamijo R, Vilcek $J$, Zinkernagel RM, Aguet M. Immune response in mice that lack the interferon-gamma receptor. Science. 1993;259:1742-5.

48. Rothe J, Lesslauer W, Lotscher H, Lang Y, Koebel P, Kontgen F, Althage A, Zinkernagel R, Steinmetz M, Bluethmann H. Mice lacking the tumour necrosis factor receptor 1 are resistant to TNF-mediated toxicity but highly susceptible to infection by listeria monocytogenes. Nature. 1993;364: 798-802.

49. Pfeffer K, Matsuyama T, Kundig TM, Wakeham A, Kishihara K, Shahinian A, Wiegmann K, Ohashi PS, Kronke M, Mak TW. Mice deficient for the $55 \mathrm{kd}$ tumor necrosis factor receptor are resistant to endotoxic shock, yet succumb to L. monocytogenes infection. Cell. 1993;73:457-67.

50. Guo Y, Niesel DW, Ziegler HK, Klimpel GR. Listeria monocytogenes activation of human peripheral blood lymphocytes: induction of non-major 
histocompatibility complex-restricted cytotoxic activity and cytokine production. Infect Immun. 1992;60:1813-9.

51. Gregory SH, Jiang X, Wing EJ. Lymphokine-activated killer cells lyse listeriainfected hepatocytes and produce elevated quantities of interferon-gamma. J Infect Dis. 1996;174:1073-9.

52. Buchmeier NA, Schreiber RD. Requirement of endogenous interferongamma production for resolution of listeria monocytogenes infection. Proc Natl Acad Sci U S A. 1985;82:7404-8.

53. Pappu R, Ramirez-Carrozzi V, Ota N, Ouyang W, Hu Y. The IL-17 family cytokines in immunity and disease. J Clin Immunol. 2010;30:185-95.

54. Ouyang W, Kolls JK, Zheng Y. The biological functions of T helper 17 cell effector cytokines in inflammation. Immunity. 2008;28:454-67.

55. Couper KN, Blount DG, Riley EM. IL-10: the master regulator of immunity to infection. J Immunol. 2008;180:5771-7.

56. Dai WJ, Kohler G, Brombacher F. Both innate and acquired immunity to listeria monocytogenes infection are increased in IL-10-deficient mice. J Immunol. 1997;158:2259-67.

57. Wagner RD, Maroushek NM, Brown JF, Czuprynski CJ. Treatment with antiinterleukin-10 monoclonal antibody enhances early resistance to but impairs complete clearance of listeria monocytogenes infection in mice. Infect Immun. 1994:62:2345-53.

58. Auerbuch V, Brockstedt DG, Meyer-Morse N, O'Riordan M, Portnoy DA. Mice lacking the type I interferon receptor are resistant to listeria monocytogenes. J Exp Med. 2004;200:527-33.

59. Carrero JA, Calderon B, Unanue ER. Type I interferon sensitizes lymphocytes to apoptosis and reduces resistance to listeria infection. J Exp Med. 2004; 200:535-40.

60. O'Connell RM, Saha SK, Vaidya SA, Bruhn KW, Miranda GA, Zarnegar B, Perry AK, Nguyen BO, Lane TF, Taniguchi T, et al. Type I interferon production enhances susceptibility to Listeria monocytogenes infection. J Exp Med. 2004;200:437-45.

61. Koopmans MM, Brouwer MC, Geldhoff M, Seron MV, Houben J, van der Ende $A$, van de Beek D. Cerebrospinal fluid inflammatory markers in patients with listeria monocytogenes meningitis. BBA Clin. 2014;1:44-51.

62. Kremer PH, Lees JA, Koopmans MM, Ferwerda B, Arends AW, Feller MM, Schipper K, Valls Seron M, van der Ende A, Brouwer MC, et al. Benzalkonium tolerance genes and outcome in listeria monocytogenes meningitis. Clin Microbiol Infect. 2017;23:265.e1-265.e7.

63. Drevets DA. Dissemination of listeria monocytogenes by infected phagocytes. Infect Immun. 1999;67:3512-7.

64. Drevets DA, Sawyer RT, Potter TA, Campbell PA. Listeria monocytogenes infects human endothelial cells by two distinct mechanisms. Infect Immun. 1995;63:4268-76

65. Wilson SL, Drevets DA. Listeria monocytogenes infection and activation of human brain microvascular endothelial cells. J Infect Dis. 1998;178: 1658-66.

66. Blanot S, Joly MM, Vilde F, Jaubert F, Clement O, Frija G, Berche P. A gerbil model for rhombencephalitis due to listeria monocytogenes. Microb Pathog. 1997;23:39-48.

67. Dramsi S, Dehoux P, Lebrun M, Goossens PL, Cossart P. Identification of four new members of the internalin multigene family of listeria monocytogenes EGD. Infect Immun. 1997;65:1615-25.

68. Ghosh P, Halvorsen EM, Ammendolia DA, Mor-Vaknin N, O'Riordan MXD, Brumell JH, Markovitz DM, Higgins DE. Invasion of the brain by listeria monocytogenes is mediated by InIF and host cell Vimentin. MBio. 2018;9

69. Moura A, Criscuolo A, Pouseele H, Maury MM, Leclercq A, Tarr C, Bjorkman JT, Dallman T, Reimer A, Enouf V, et al. Whole genome-based population biology and epidemiological surveillance of listeria monocytogenes. Nat Microbiol. 2016:2:16185.

70. Lee S, Ward TJ, Jima DD, Parsons C, Kathariou S. The arsenic resistanceassociated listeria genomic island $\mathrm{LG} 2$ exhibits sequence and integration site diversity and a propensity for three listeria monocytogenes clones with enhanced virulence. Appl Environ Microbiol. 2017;83.

71. Gray ML, Killinger AH. Listeria monocytogenes and listeric infections. Bacteriol Rev. 1966;30:309-82.

72. Kasanmoentalib ES, Valls Seron M, Ferwerda B, Tanck MW, Zwinderman AH, Baas F, van der Ende A, Brouwer MC, van de Beek D. Mannose-binding lectin-associated serine protease 2 (MASP-2) contributes to poor disease outcome in humans and mice with pneumococcal meningitis. J Neuroinflammation. 2017:14:2.
73. Mook-Kanamori BB, Valls Seron M, Geldhoff M, Havik SR, van der Ende A, Baas F, van der Poll T, Meijers JC, B PM, Brouwer MC, van de Beek D. Thrombin-activatable fibrinolysis inhibitor influences disease severity in humans and mice with pneumococcal meningitis. J Thromb Haemost. 2015; 13:2076-86.

74. Geldhoff M, Mook-Kanamori BB, Brouwer MC, Troost D, Leemans JC, Flavell RA, Van der Ende A, Van der Poll T, Van de Beek D. Inflammasome activation mediates inflammation and outcome in humans and mice with pneumococcal meningitis. BMC Infect Dis. 2013;13:358.

\section{Ready to submit your research? Choose BMC and benefit from:}

- fast, convenient online submission

- thorough peer review by experienced researchers in your field

- rapid publication on acceptance

- support for research data, including large and complex data types

- gold Open Access which fosters wider collaboration and increased citations

- maximum visibility for your research: over $100 \mathrm{M}$ website views per year

At BMC, research is always in progress.

Learn more biomedcentral.com/submissions 